\title{
Human health risk assessment of heavy metals from a crude oil polluted agricultural soil in Ogoniland, Nigeria
}

\section{Chukwuemeka C. Chukwuma*, Chigozie Linda Onuah and Michael Okechukwu Monanu}

Department of Biochemistry. Faculty of Science. University of Port Harcourt. PMB 5239 Choba. Rivers State. Nigeria. *Email: matrix4war2001@yahoo.com.

\begin{abstract}
Heavy metal contamination of agricultural soils can instigate risk to human health via oral ingestion, particle inhalation, and dermal contact. The study evaluates the concentrations, distribution, and human health risk of various heavy metals in soil samples from crude oil polluted agricultural soil of Ogoniland, Nigeria. Soil samples were collected and analyzed for cadmium, lead, chromium, copper, iron, manganese, zinc, arsenic and mercury using AAS (SensAA). Measured concentrations of these heavy metals were employed to calculate the health risk for children and adults using Hazard Index (HI). For the children and adult population, the HI value for oral ingestion to lead in the polluted site was greater than one ( $\mathrm{HI}>1$ ), and hence non-carcinogenic effects is considered as significant for human health. It is therefore of the essence to consider taking risk management measures in order to reduce the risk of human health from lead.
\end{abstract}

Keywords: Risk assessment; Heavy metals; Polluted soil; Hazard quotient; Hazard index; Average daily intake; Carcinogenic risk; Non-carcinogenic risk.

\section{Introduction}

Heavy metals are elements of biological toxicity that arise naturally, and encompass high atomic weight and density, about 5 times exceeding water (Su et al., 2014). They naturally arise via
Received

January 29, 2019

Accepted

April 23, 2019

Released

April 30, 2019

Full Text Article

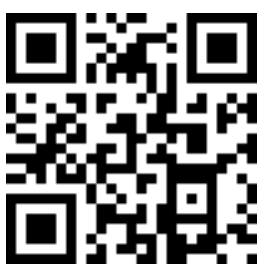

ORCID
0000-0002-3803-1203
Chukwuemeka C.
Chukwuma
0000-0003-3373-8645
Chigozie Linda Onuah
0000-0002-8171-8895
Michael Okechukwu
Monanu weathering processes at levels $<1,000$ $\mathrm{mg} / \mathrm{kg}$ and could also arise from anthropogenic activities such as mining activities, pesticides usage, phosphate fertilizers, photographic materials, printing pigments, sewage irrigation, smelting, steel and electroplating 
industries, textiles, and dye and wood preservation (Wuana and Okieimen, 2011).They include Arsenic (As), Mercury (Hg), Lead (Pb), Cadmium (Cd), Chromium (Cr) etc. Heavy metals are deemed as trace and consequently rarely toxic and are not readily available to living organisms due to their vast adsorption capacity on soil (Ayangbenro and Babalola, 2017). Heavy metals are appraised as systemic toxicants with prospective to incite multiple organ damage even at minimal exposure levels and are classified as known carcinogens (IARC, 1993; USEPA, 2006).

There also exist other heavy metals of definite biological toxicity such as Zinc (Zn), Copper (Cu), Nickel (Ni), Selenium (Sn) and Vanadium (V) (Su et al., 2014). Heavy metals such as Cobalt (Co), Copper (Cu), Chromium (Cr), Iron $(\mathrm{Fe})$, Manganese $(\mathrm{Mn}), \quad$ Molybdenum (Mo), Nickel (Ni), Selenium (Se) and Zinc (Zn) have been appraised as essential nutrients requisite for several physiological and biological functions whose inadequate provision can be consequential in an array of deficiency syndromes or diseases. Other metals such as Aluminum (Al), Antimony ( $\mathrm{Sb}$ ), Barium (Ba), Beryllium (Be), Bismuth (Bi), Gallium (Ga), Germanium (Ge), Gold
$(\mathrm{Au})$, Indium (In), Lithium (Li), Platinum $(\mathrm{Pt})$, Silver (Ag), Strontium (Sr), Tellurium (Te), Thallium (Tl), Tin (Sn), Titanium, Vanadium (V) and Uranium (U) have no entrenched biological function and consequently evaluated as non-essential (Tchounwou et al., 2012). Heavy metal contamination is hence defined as immoderate deposition of toxic heavy metals in the soil due to human activities (Su et al., 2014).

The heavy metals type, level and form depend on the sort of action that takes place at the site. New Jersey Department of Environmental Protection (NJDEP, 1996) and Department of Petroleum Resources (DPR, 2002) listed some ranges and guidelines for some heavy metals (Table 1). The DPREGASPIN has recommended guidelines on remediation of contaminated site based on intervention values and target values. The intervention values symbolize the quality at which the proper functionality of the soil for living organisms is threatened (Table 2). Values higher than the intervention values designate serious contaminations (Table 3), while the target values designate the required soil quality for sustainability (DPR, 2002).

Table 1. Soil concentration ranges and regulatory guideline for some heavy metals.

\begin{tabular}{|c|c|c|}
\hline Metal & Soil concentration range (mg.kg $\left.{ }^{-1}\right)^{*}$ & Regulatory limits (mg.kg-1)** \\
\hline $\mathrm{Pb}$ & $1.00-69,000$ & 600 \\
\hline $\mathrm{Cd}$ & $0.10-345$ & 100 \\
\hline $\mathrm{Cr}$ & $0.05-3,950$ & 100 \\
\hline $\mathrm{Hg}$ & $<0.01-1,800$ & 270 \\
\hline $\mathrm{Zn}$ & $150-5,000$ & 1,500 \\
\hline
\end{tabular}

Sources: Riley et al. (1992)*; NJDEP (1996)**. 
Table 2. Target and intervention values for some metals for a standard soil.

\begin{tabular}{ccc}
\hline Metal & Target value $\mathbf{( m g . k g - \mathbf { ~ }})$ & Intervention value (mg.kg-1) \\
\hline $\mathrm{Ni}$ & 140 & 720 \\
$\mathrm{Cu}$ & 0.3 & 10 \\
$\mathrm{Zn}$ & $\mathrm{n} . \mathrm{a}$ & $\mathrm{n} . \mathrm{a}$ \\
$\mathrm{Cd}$ & 100 & 380 \\
$\mathrm{~Pb}$ & 35 & 210 \\
$\mathrm{As}$ & 200 & 625 \\
$\mathrm{Cr}$ & 20 & 240 \\
$\mathrm{Hg}$ & 85 & 530 \\
\hline
\end{tabular}

Source: DPR (2002). n.a.: not available.

Table 3. Maximum allowable limit of concentrations of some heavy metals in soil $\left(\mathrm{mg}^{\mathrm{kg}} \mathrm{kg}^{-1}\right)$ for Different Countries.

\begin{tabular}{|c|c|c|c|c|c|c|c|c|c|}
\hline Country & As & $\mathbf{P b}$ & $\mathrm{Hg}$ & Cd & $\mathrm{Cr}$ & $\mathrm{Cu}$ & Zn & Co & $\mathbf{N i}$ \\
\hline Germany & 50 & 70.0 & 0.5 & 1.0 & 60.0 & 40.0 & 150.0 & n.a. & 50.0 \\
\hline Poland & n.a. & 100 & n.a. & 3 & 100 & 100 & 300 & 50 & 100 \\
\hline UK & 32 & 450 & 10 & 10 & 130 & n.a. & n.a. & n.a. & 130 \\
\hline Australia & 20 & 300 & 1 & 3 & 50 & 100 & 200 & n.a. & 60 \\
\hline Taiwan & 60 & 300 & 2 & 5 & 250 & 200 & 600 & n.a. & 200 \\
\hline Bulgaria & 10 & 26 & 0.03 & 0.4 & 65 & 34 & 88 & 20 & 46 \\
\hline Canada & 20 & 200 & 0.8 & 3 & 250 & 150 & 500 & n.a. & 100 \\
\hline China & 30 & 80 & 0.7 & 0.5 & 200 & 100 & 250 & n.a. & 50 \\
\hline Tanzania & 1 & 200 & 2 & 1 & 100 & 200 & 150 & n.a. & 100 \\
\hline $\begin{array}{l}\text { FAO/WHO } \\
\text { Guidelines }\end{array}$ & 20 & 100 & n.a. & 3 & 100 & 100 & 300 & 50 & 50 \\
\hline EU Guidelines & n.a. & 300 & n.a. & 3 & 150 & 140 & 300 & n.a. & 75 \\
\hline South Africa & 5.8 & 20 & 0.93 & 7.5 & 6.5 & 16 & 240 & 300 & 91 \\
\hline
\end{tabular}

Source: Kamunda et al. (2016). n.a.: not available.

\section{Materials and methods}

\section{Study area}

The study area is a crude oil polluted agricultural farmland located in Bodo community of Ogoniland,Rivers State, Nigeria. Ogoniland has a terrific account of crude oil pollution which is mostly caused as a result of anthropogenic activities. Ogoniland covers about $1000 \mathrm{~km}^{2}$ in South-East of Niger Delta and with populace close to 832,000 (Chukwuma et al., 2018).

\section{preparation}

\section{Sampling and sample}

Soil samples were randomly collected from the polluted and unpolluted sites with steel auger at a depth of 0-15 cm. At each sampling location, five replicate samples were collected, homogenized, out of which $1 \mathrm{~kg}$ was packaged in polyethylene bags. The collected samples were marked for easy identification and taken to the laboratory for further processing and analysis. At the laboratory, the soil samples were first spread out on a plastic sheet and allowed to air dry for 2-3 days. The samples were thereafter sieved through a $2 \mathrm{~mm}$ nylon mesh to obtain a homogenized sample matrix. Attention was paid to every sample to avoid crosscontamination (Kamunda et al., 2016 $a, b)$.

\section{Soil sample analysis}

Heavy metals analyses were conducted at $60{ }^{\circ} \mathrm{C}$ by microwave digestion method as adapted by 
Mwegoha and Kihampa (2010) and Rashid et al. (2016). Two and half grams of fine powdered soil was transferred to crucible and mixed with $10 \mathrm{~mL}$ of aqua regia comprising of $\mathrm{HCl}$ and $\mathrm{HNO}_{3}(3: 1)$, and further digested at $95^{\circ} \mathrm{C}$ for $1 \mathrm{~h}$. This was diluted to $50 \mathrm{~mL}$ using $\mathrm{dH}_{2} 0$ after cooling and left to settle overnight, and thereafter filtered. The concentrations of $\mathrm{Pb}, \mathrm{Cd}, \mathrm{Cr}, \mathrm{Zn}, \mathrm{Mn}, \mathrm{Cu}, \mathrm{Fe}, \mathrm{As}$, and $\mathrm{Hg}$ were determined by atomic absorption spectrometry (SensAA).

\section{Health risk evaluation \\ Theory of Risk Assessment.}

Human health risk assessment is a process used to estimate the health effects resulting from exposure to carcinogenic and non-carcinogenic chemicals (Kamunda, Mathuthu and Madhuku, 2016). The risk assessment process is made up of four basic steps: hazard identification, exposure assessment, toxicity (dose-response) assessment, and risk characterization (USEPA, 2001).

Hazard Identification basically aims to investigate chemicals that are present at any given location, their concentrations, and spatial distribution.
The purpose of exposure assessment is to measure or estimate the intensity, frequency, and duration of human exposures to an environmental contaminant (Šukalić et al., 2018). Exposure assessment can be carried out by measuring the average daily intake (ADI) of heavy metals through ingestion, inhalation and dermal contact by adults and children (Kamunda et al., 2016). Adults and children are separated because of their behavioural and physiological differences (Wang, Sato and Xing, 2005).

Dose-response assessment estimates the toxicity due to exposure levels of chemicals (Table 4). The cancer slope factor $(C S F$, a carcinogen potency factor) and the reference dose ( $R f D$, a non-carcinogenic threshold) are two important toxicity indices used. $R f D$ values are derived from animal studies using the "No observable effect level" principle. For humans, RfD values are multiplied 10-fold to account for uncertainties (USEPA, 1989).

Table 4. Exposure parameters used for the health risk assessment for standard residential exposure scenario through different exposure pathways.

\begin{tabular}{lccc}
\hline Parameter & Unit & Child & Adult \\
\hline Body weight $(B W)$ & $\mathrm{kg}$ & 15 & 70 \\
Exposure frequency $(E F)$ & days/year & 350 & 350 \\
Exposure duration $(E D)$ & years & 6 & 30 \\
Ingestion rate $(I R)$ & $\mathrm{mg} / \mathrm{day}$ & 200 & 100 \\
Inhalation rate $(I R$ air $)$ & $\mathrm{m}^{3} / \mathrm{day}$ & 10 & 20 \\
Skin surface area $(S A)$ & $\mathrm{cm}^{2}$ & 2,100 & 5,800 \\
Soil adherence factor $(A F)$ & $\mathrm{mg}^{2} / \mathrm{cm}^{2}$ & 0.2 & 0.07 \\
Dermal Absorption factor $(A B S)$ & None & 0.1 & 0.1 \\
Dermal exposure ratio $(F E)$ & None & 0.61 & 0.61 \\
Particulate emission factor $(P E F)$ & $\mathrm{m}^{3} / \mathrm{kg}$ & $1.3 \times 10^{9}$ & $1.3 \times 10^{9}$ \\
Conversion factor $(C F)$ & $\mathrm{kg} / \mathrm{mg}$ & $10^{-6}$ & $10^{-6}$ \\
Average time $(A T)$ & & & $365 \times 70$ \\
For carcinogens & days & $365 \times 70$ & $365 \times \mathrm{ED}$ \\
For non-carcinogens & & $365 \times \mathrm{ED}$ & \\
\hline
\end{tabular}

Source: Kamunda et al. (2016). 
Risk characterization predicts the potential cancerous and noncancerous health risk of children and adults in the study area by integrating all the information gathered to arrive at quantitative estimates of cancer risk and hazard indices (USEPA, 2004).

The potential exposure pathways for heavy metals in

Ingestion of heavy metals through soil

$$
\mathrm{ADI}_{\text {ing }}=\frac{\mathrm{C} \times \mathrm{IR} \times \mathrm{EF} \times \mathrm{ED} \times \mathrm{CF}}{\mathrm{BW} \times \mathrm{AT}}
$$

Where: $A D I_{\text {ing }}$ is the average daily intake of heavy metals ingested from soil in $\mathrm{mg} / \mathrm{kg}$-day, $C=$ concentration of heavy metal in $\mathrm{mg} / \mathrm{kg}$ for soil. $I R$ in $\mathrm{mg} /$ day is the ingestion rate, $E F$ in days/year is the exposure frequency, $E D$ is the exposure contaminated soils are calculated based on recommendations by several American publications. ADI $(\mathrm{mg} / \mathrm{kg}$ day) for the different pathways are calculated using the following exposure Equations (1) to Equations (3) as prescribed by USEPA (1989).

\section{Inhalation of heavy metals via soil particulates}

$$
\mathrm{ADI}_{\mathrm{inh}}=\frac{\text { CxIRair } \times \mathrm{EF} \times \mathrm{ED}}{\mathrm{PEF} \times \mathrm{BW} \times \mathrm{AT}} \quad \text { Equation 2 }
$$

Where: $A D I_{\text {inh }}$ is the average daily intake of heavy metals inhaled from soil in $\mathrm{mg} / \mathrm{kg}$-day, $C_{S}$ is the concentration of heavy metal in soil in $\mathrm{mg} / \mathrm{kg}, I R_{\text {air }}$ is the inhalation rate in $\mathrm{m}^{3} /$ day, $P E F$, is the particulate emission factor in $\mathrm{m}^{3} / \mathrm{kg}$. $E F$, $E D, B W$ and $A T$ are as defined earlier in Equation (1).

\section{Dermal contact with soil}

$$
\mathrm{ADI}_{\text {derm }}=\frac{\mathrm{C} \times \mathrm{SA} \times \mathrm{FE} \times \mathrm{AF} \times \mathrm{ABS} \times \mathrm{EF} \times \mathrm{ED} \times \mathrm{CF}}{\mathrm{BW} \times \mathrm{AT}} \quad \text { Equation } 3
$$

Where: $A D I_{\text {dems }}$ is the exposure dose via dermal contact in $\mathrm{mg} / \mathrm{kg} /$ day. $C_{S}$ is the concentration of heavy metal in soil in $\mathrm{mg} / \mathrm{kg}, S A$ is exposed skin area in $\mathrm{cm}^{2}, F E$ is the fraction of the dermal exposure ratio to soil, $A F$ is the soil adherence factor in $\mathrm{mg} / \mathrm{cm}^{2}, A B S$ is the fraction of the applied dose absorbed across the skin. $E F, E D, B W, C F$ and $A T$ are as defined earlier in Equation (1).

\section{Non carcinogenic risk assessment}

Non-carcinogenic hazards are characterized by a term called hazard quotient $(H Q)$. HQ is the statistical term of the ratio of two variables that expresses the likelihood of an adverse effect on an individual (Šukalić et al., 2018). It is a unitless number that is expressed as the probability of an individual suffering an 
adverse effect. It is defined as the quotient of $A D I$ or dose divided by the toxicity threshold value, which is referred

$$
\mathrm{HQ}=\frac{\mathrm{ADI}}{R f D}
$$

For $n$ number of heavy metals, the non-carcinogenic effect to the population is as a result of the summation of all the HQs due to individual heavy metals. This is considered to be another term called the

$$
\mathrm{HI}=\sum_{k=1}^{n} \mathrm{HQk}=\sum_{k=1}^{n} \frac{A D I k}{R f D k}
$$

where $H Q_{k}, A D I_{k}$ and $R f D_{k}$ are values of heavy metal $k$. If the $H I$ value is less than one, the exposed population is unlikely to experience adverse health effects. If the $H I$ value exceeds one, then there may be concern for potential non-carcinogenic effects (U.S. Environmental Protection Agency, 2004).

$$
\text { Riskpathway }=\sum_{k=1}^{n} \mathrm{ADI} \text {. CSF } k
$$

where Risk is a unitless probability of an individual developing cancer over a lifetime. ADI $k(\mathrm{mg} / \mathrm{kg} /$ day $)$ and $\mathrm{CSF} k$ $\left(\mathrm{mg} / \mathrm{kg} / \mathrm{day}^{-1}\right.$ are the average daily intake and the cancer slope factor, respectively for the kth heavy metal, for $n$ number of heavy metals. The slope factor converts the estimated daily intake of the heavy metal averaged over a lifetime of to as the chronic reference dose (RfD) in $\mathrm{mg} / \mathrm{kg}$-day of a specific heavy metal as shown in Equation (4) (USEPA, 2004).

Equation 4

Hazard Index $(H I)$ as described by USEPA document USEPA (U.S. Environmental Protection Agency, 2004). Equation (5) shows the mathematical representation of this parameter:
Equation 5

\section{Carcinogenic risk assessment}

For carcinogens, the risks are estimated as the incremental probability of an individual developing cancer over a lifetime as a result of exposure to the potential carcinogen (Kamunda et al., 2016). The equation for calculating the excess lifetime cancer risk is:

Equation 6

exposure directly to incremental risk of an individual developing cancer (U.S. Environmental Protection Agency, 2004).

The total excess lifetime cancer risk for an individual is finally calculated from the average contribution of the individual heavy metals for all the pathways using the following equation:

$$
\operatorname{Risk}(\text { total })=\operatorname{Risk}(\text { ing })+\operatorname{Risk}(\text { inh })+\operatorname{Risk}(\text { dermal }) \quad \text { Equation } 7
$$

where Risk (ing), Risk (inh), and Risk (dermal) are risks contributions through ingestion, inhalation and dermal pathways. 
Both non-carcinogenic and carcinogenic risk assessment of heavy metals are calculated using RfD and CSF values derived largely from the
Department of Environmental Affairs (South Africa) and USEPA as shown in Table 5.

Table 5. Reference doses (RfD) in (mg/kg-day) and Cancer Slope Factors (CSF) for the different heavy metals.

\begin{tabular}{|c|c|c|c|c|c|c|}
\hline $\begin{array}{l}\text { Heavy } \\
\text { Metal }\end{array}$ & $\begin{array}{l}\text { Oral } \\
R f D^{\text {Dermal }}\end{array}$ & Dermal RfD & $\begin{array}{l}\text { Inhalation } \\
\text { RfD }\end{array}$ & $\begin{array}{l}\text { Oral } C S F \\
\text { Dermal }\end{array}$ & $\begin{array}{l}\text { Dermal } \\
\text { CSF }\end{array}$ & $\begin{array}{l}\text { Inhalation } \\
\text { CSF }\end{array}$ \\
\hline As & $3.00 \mathrm{E}-04$ & $3.00 \mathrm{E}^{-04}$ & $3.00 \mathrm{E}-04$ & $1.50 \mathrm{E}+00$ & $1.50 \mathrm{E}+00$ & $1.50 \mathrm{E}+00$ \\
\hline $\mathrm{Pb}$ & $3.60 \mathrm{E}-03$ & - & - & $8.50 \mathrm{E}-03$ & - & $4.20 \mathrm{E}+02$ \\
\hline $\mathrm{Hg}$ & $3.00 \mathrm{E}-04$ & $3.00 \mathrm{E}^{-04}$ & $8.60 \mathrm{E}-05$ & - & - & - \\
\hline $\mathrm{Cd}$ & $5.00 \mathrm{E}-04$ & $5.00 \mathrm{E}^{-} 04$ & $5.70 \mathrm{E}^{-0} 05$ & ـ & - & $6.30 \mathrm{E}+00$ \\
\hline $\mathrm{Cr}(\mathrm{VI})$ & $3.00 \mathrm{E}-03$ & - & $3.00 \mathrm{E}^{-0} 05$ & $5.00 \mathrm{E}-01$ & - & $4.10 \mathrm{E}+01$ \\
\hline Co & $2.00 \mathrm{E}-02$ & $5.70 \mathrm{E}^{-06}$ & $5.70 \mathrm{E}-06$ & - & - & $9.80 \mathrm{E}+00$ \\
\hline $\mathrm{Ni}$ & $2.00 \mathrm{E}-02$ & $5.60 \mathrm{E}^{-} 03$ & - & - & - & - \\
\hline $\mathrm{Cu}$ & $3.70 \mathrm{E}^{-0} 02$ & $2.40 \mathrm{E}^{-} 02$ & - & - & - & - \\
\hline $\mathrm{Zn}$ & $3.00 \mathrm{E}^{-0}-1$ & $7.50 \mathrm{E}^{-} 02$ & - & - & - & - \\
\hline
\end{tabular}

Source: Kamunda et al. (2016).

\section{Results and discussion}

\section{Concentrations of heavy metals} in soils from the polluted and unpolluted site

The result presented in Table 6 showed that the mean triplicate determination of the concentration of the heavy metals from the polluted and unpolluted soil areas. For the polluted soil, the heavy metals concentrations were as follows: cadmium $(6.27 \mathrm{mg} / \mathrm{kg})$, lead $(390.37 \mathrm{mg} / \mathrm{kg}$ ), chromium (143.66 $\mathrm{mg} / \mathrm{kg}$ ), copper (12.81 mg/kg), iron
$(820.60 \mathrm{mg} / \mathrm{kg})$, manganese $(820.78$ $\mathrm{mg} / \mathrm{kg})$, zinc $(158.94 \mathrm{mg} / \mathrm{kg})$, arsenic $(3.16 \mathrm{mg} / \mathrm{kg})$ and mercury $(0.00 \mathrm{~kg} / \mathrm{mg})$; while for the unpolluted soil, the heavy metals concentrations were as follows; cadmium (3.21 mg/kg), lead $(104.45$ $\mathrm{mg} / \mathrm{kg})$, chromium $(71.50 \mathrm{mg} / \mathrm{kg})$, copper $(1.48 \mathrm{mg} / \mathrm{kg})$, iron $(436.01$ $\mathrm{mg} / \mathrm{kg})$, manganese $(43.31 \mathrm{mg} / \mathrm{kg})$, zinc $(55.85 \mathrm{mg} / \mathrm{kg})$, arsenic $(0.00 \mathrm{mg} / \mathrm{kg})$ and mercury $\quad(0.00 \quad \mathrm{~kg} / \mathrm{mg})$. These concentrations were used to calculate average daily intake for non-carcinogenic and carcinogenic risk assessment.

Table 6. Mean Heavy metal concentration by the soil groups (mg/kg).

\begin{tabular}{lccccccccc}
\hline & Cadmium & Lead & Chromium & Copper & Iron & Manganese & Zinc & As & Hg \\
\hline Polluted & 6.27 & 390.37 & 143.66 & 12.81 & 820.60 & 820.78 & 158.94 & 3.16 & 0.00 \\
Unpolluted & 3.21 & 104.45 & 71.50 & 1.48 & 436.01 & 43.31 & 55.85 & 0.00 & 0.00 \\
\hline
\end{tabular}




\section{Non carcinogenic risk of heavy metals for children and adults}

Non carcinogenic risk of adults and children were calculated based on RFD values as presented in Table 5 and
ADI values in Tables 7 to 10 . These results for ingestion, inhalation and dermal pathways are all presented in terms of HQs as shown in Tables 11 to 14.

Table 7. Average Daily Intake (ADI) values in $\mathrm{mg} / \mathrm{kg} / \mathrm{day}$ for adults and children in soil from the polluted site for non-carcinogenic risk assessment.

\begin{tabular}{|c|c|c|c|c|c|c|c|c|c|c|c|}
\hline \multirow{2}{*}{\multicolumn{2}{|c|}{ Receptor pathway }} & \multicolumn{9}{|c|}{ Average Daily Intake (ADI) values for heavy metals in mg/kg/day } & \multirow{2}{*}{ Total } \\
\hline & & Cd & $\mathrm{Pb}$ & $\mathrm{Cr}$ & $\mathrm{Cu}$ & $\mathrm{Fe}$ & Mn & $\mathrm{Zn}$ & As & $\mathrm{Hg}$ & \\
\hline \multirow{4}{*}{ Adults } & Ingestion & $8.59 \mathrm{E}-06$ & 5.35E-04 & 1.97E-04 & $1.75 \mathrm{E}-05$ & $1.12 \mathrm{E}-03$ & $1.11 \mathrm{E}-03$ & $2.18 \mathrm{E}-04$ & $4.33 \mathrm{E}-06$ & 0.00 & $3.23 \mathrm{E}-03$ \\
\hline & Inhalation & $1.32 \mathrm{E}-09$ & 8.23E-08 & $3.03 \mathrm{E}-08$ & $2.70 \mathrm{E}-09$ & $1.73 \mathrm{E}-07$ & $1.73 \mathrm{E}-07$ & 3.35E-08 & $6.66 \mathrm{E}-10$ & 0.00 & $4.97 \mathrm{E}-07$ \\
\hline & Dermal & 2.13E-06 & $1.32 \mathrm{E}-04$ & $4.87 \mathrm{E}-05$ & $4.35 \mathrm{E}-06$ & 2.78E-04 & $2.78 \mathrm{E}-4$ & 5.39E-05 & $1.07 \mathrm{E}-06$ & 0.00 & 7.99E-04 \\
\hline & Total & 1.07E-05 & 6.67E-04 & $2.46 \mathrm{E}-04$ & 2.19E-05 & $1.40 \mathrm{E}-03$ & $1.40 \mathrm{E}-03$ & $2.72 \mathrm{E}-04$ & $5.40 \mathrm{E}-06$ & 0.00 & $4.02 \mathrm{E}-03$ \\
\hline \multirow{4}{*}{ Children } & Ingestion & $8.02 \mathrm{E}-05$ & $5.00 \mathrm{E}-03$ & $1.84 \mathrm{E}-03$ & $1.63 \mathrm{E}-04$ & $1.05 \mathrm{E}-02$ & $1.05 \mathrm{E}-02$ & $2.03 \mathrm{E}-03$ & $4.04 \mathrm{E}-05$ & 0.00 & $3.01 \mathrm{E}-02$ \\
\hline & Inhalation & 3.08E-09 & $1.92 \mathrm{E}-07$ & $7.06 \mathrm{E}-08$ & $6.30 \mathrm{E}-09$ & $4.04 \mathrm{E}-07$ & $4.04 \mathrm{E}-07$ & $7.82 \mathrm{E}-08$ & $1.55 \mathrm{E}-09$ & 0.00 & $1.16 \mathrm{E}-06$ \\
\hline & Dermal & $1.03 \mathrm{E}-05$ & $6.40 \mathrm{E}-04$ & 2.35E-04 & $2.10 \mathrm{E}-05$ & $1.34 \mathrm{E}-03$ & $1.34 \mathrm{E}-03$ & $2.60 \mathrm{E}-04$ & $5.18 \mathrm{E}-06$ & 0.00 & $3.85 \mathrm{E}-03$ \\
\hline & Total & $9.04 \mathrm{E}-05$ & $5.63 \mathrm{E}-03$ & $2.07 \mathrm{E}-03$ & $1.85 \mathrm{E}-04$ & $1.18 \mathrm{E}-02$ & $1.18 \mathrm{E}-02$ & $2.29 \mathrm{E}-03$ & $4.56 \mathrm{E}-05$ & 0.00 & $3.39 \mathrm{E}-02$ \\
\hline
\end{tabular}

Table 8. Average Daily Intake (ADI) values in $\mathrm{mg} / \mathrm{kg} /$ day for adults and children in soil from the unpolluted site for non-carcinogenic risk assessment.

\begin{tabular}{|c|c|c|c|c|c|c|c|c|c|c|c|}
\hline \multirow{2}{*}{\multicolumn{2}{|c|}{ Receptor pathway }} & \multicolumn{9}{|c|}{ Average Daily Intake (ADI) values for heavy metals in mg/kg/day } & \multirow[b]{2}{*}{ Total } \\
\hline & & Cd & $\mathbf{P b}$ & $\mathrm{Cr}$ & Cu & $\mathrm{Fe}$ & $\mathrm{Mn}$ & $\mathrm{Zn}$ & As & Hg & \\
\hline \multirow{4}{*}{ Adults } & Ingestion & $4.4 \mathrm{E}-06$ & $1.43 \mathrm{E}-04$ & $9.79 \mathrm{E}-05$ & 2.03E-06 & 5.97E-04 & 5.93E-05 & $7.65 \mathrm{E}-05$ & 0.00 & 0.00 & $9.80 \mathrm{E}-04$ \\
\hline & Inhalation & $6.77 \mathrm{E}-10$ & $2.2 \mathrm{E}-08$ & $1.51 \mathrm{E}-08$ & $3.12 \mathrm{E}-10$ & $9.19 \mathrm{E}-08$ & 9.13E-09 & $1.18 \mathrm{E}-08$ & 0.00 & 0.00 & $1.51 \mathrm{E}-07$ \\
\hline & Dermal & $1.09 \mathrm{E}-06$ & $3.54 \mathrm{E}-05$ & $2.43 \mathrm{E}-05$ & $5.02 \mathrm{E}-07$ & $1.48 \mathrm{E}-04$ & 1.47E-05 & $1.89 \mathrm{E}-05$ & 0.00 & 0.00 & 2.43E-04 \\
\hline & Total & $5.49 \mathrm{E}-06$ & $1.78 \mathrm{E}-04$ & $1.22 \mathrm{E}-04$ & $2.53 \mathrm{E}-06$ & $7.45 \mathrm{E}-04$ & $7.40 \mathrm{E}-05$ & $9.54 \mathrm{E}-05$ & 0.00 & 0.00 & $1.22 \mathrm{E}-03$ \\
\hline \multirow{4}{*}{ Children } & Ingestion & $4.1 \mathrm{E}-05$ & $1.34 \mathrm{E}-04$ & $9.14 \mathrm{E}-04$ & $1.89 \mathrm{E}-05$ & $5.58 \mathrm{E}-03$ & $5.54 \mathrm{E}-04$ & $7.14 \mathrm{E}-04$ & 0.00 & 0.00 & $9.15 \mathrm{E}-03$ \\
\hline & Inhalation & $1.58 \mathrm{E}-09$ & $5.14 \mathrm{E}-08$ & $3.52 \mathrm{E}-08$ & $7.28 \mathrm{E}-10$ & $2.14 \mathrm{E}-07$ & $2.13 \mathrm{E}-08$ & $2.75 \mathrm{E}-08$ & 0.00 & 0.00 & $3.52 \mathrm{E}-07$ \\
\hline & Dermal & $5.26 \mathrm{E}-06$ & $1.710 \mathrm{E}-04$ & $1.17 \mathrm{E}-04$ & $2.42 \mathrm{E}-06$ & $7.14 \mathrm{E}-04$ & $7.09 \mathrm{E}-05$ & $9.15 \mathrm{E}-05$ & 0.00 & 0.00 & 1.17E-03 \\
\hline & Total & $4.63 \mathrm{E}-05$ & $1.51 \mathrm{E}-03$ & $1.03 \mathrm{E}-03$ & $2.13 \mathrm{E}-05$ & $6.29 \mathrm{E}-03$ & $6.25 \mathrm{E}-04$ & $8.06 \mathrm{E}-04$ & 0.00 & 0.00 & $1.03 \mathrm{E}-02$ \\
\hline
\end{tabular}

Table 9. Average Daily Intake (ADI) values in $\mathrm{mg} / \mathrm{kg} / \mathrm{day}$ for adults and children in soil from the polluted site for carcinogenic risk assessment.

\begin{tabular}{|c|c|c|c|c|c|c|c|c|c|c|c|}
\hline \multirow{2}{*}{\multicolumn{2}{|c|}{ Receptor pathway }} & \multicolumn{9}{|c|}{ Average Daily Intake (ADI) values for heavy metals in $\mathrm{mg} / \mathrm{kg} /$ day } & \multirow[b]{2}{*}{ Total } \\
\hline & & $\mathrm{Cd}$ & $\mathrm{Pb}$ & $\mathrm{Cr}$ & $\mathrm{Cu}$ & $\mathrm{Fe}$ & Mn & $\mathrm{Zn}$ & As & $\mathrm{Hg}$ & \\
\hline \multirow{4}{*}{ Adults } & Ingestion & $3.68 \mathrm{E}-05$ & $2.29 \mathrm{E}-03$ & 8.43E-04 & $7.52 \mathrm{E}-05$ & $4.82 \mathrm{E}-03$ & $4.82 \mathrm{E}-03$ & $9.33 \mathrm{E}-04$ & $1.86 \mathrm{E}-05$ & 0.00 & 1.38E-02 \\
\hline & Inhalation & $5.66 \mathrm{E}-10$ & $3.53 \mathrm{E}-08$ & $1.30 \mathrm{E}-08$ & $1.16 \mathrm{E}-09$ & $7.41 \mathrm{E}-08$ & 7.41E-08 & $1.44 \mathrm{E}-08$ & $2.85 \mathrm{E}-10$ & 0.00 & 2.13E- 07 \\
\hline & Dermal & 9.12E-07 & $5.68 \mathrm{E}-05$ & $2.09 \mathrm{E}-05$ & $1.86 \mathrm{E}-06$ & $1.19 \mathrm{E}-04$ & 1.19E-04 & $2.31 \mathrm{E}-05$ & 4.59E-07 & 0.00 & 3.42E-04 \\
\hline & Total & 3.77E-05 & 2.35E-03 & 8.64E-04 & 7.71E-05 & 4.94E-03 & $4.94 \mathrm{E}-03$ & $9.56 \mathrm{E}-04$ & $1.91 \mathrm{E}-05$ & 0.00 & $1.42 \mathrm{E}-02$ \\
\hline \multirow{4}{*}{ Children } & Ingestion & 6.87E-06 & $4.28 \mathrm{E}-04$ & 1.57E-04 & $1.40 \mathrm{E}-05$ & $9.00 \mathrm{E}-04$ & $9.00 \mathrm{E}-04$ & $1.74 \mathrm{E}-04$ & $3.46 \mathrm{E}-06$ & 0.00 & $2.58 \mathrm{E}-03$ \\
\hline & Inhalation & $2.64 \mathrm{E}-10$ & 1.65E-08 & $6.06 \mathrm{E}-09$ & $5.40 \mathrm{E}-10$ & $3.46 \mathrm{E}-08$ & $3.46 \mathrm{E}-08$ & $6.70 \mathrm{E}-09$ & $1.33 \mathrm{E}-10$ & 0.00 & $9.92 \mathrm{E}-08$ \\
\hline & Dermal & $8.80 \mathrm{E}-07$ & $5.48 \mathrm{E}-05$ & $2.02 \mathrm{E}-05$ & $1.80 \mathrm{E}-06$ & $1.15 \mathrm{E}-04$ & $1.15 \mathrm{E}-04$ & $2.23 \mathrm{E}-05$ & $4.44 \mathrm{E}-07$ & 0.00 & $3.30 \mathrm{E}-04$ \\
\hline & Total & $7.75 \mathrm{E}-06$ & 4.83E-04 & $1.78 \mathrm{E}-04$ & $1.58 \mathrm{E}-05$ & $1.01 \mathrm{E}-03$ & $1.01 \mathrm{E}-03$ & 1.97E-04 & $3.90 \mathrm{E}-06$ & 0.00 & $2.91 \mathrm{E}-03$ \\
\hline
\end{tabular}

Table 10. Average Daily Intake (ADI) values in $\mathrm{mg} / \mathrm{kg} /$ day for adults and children in soil from the unpolluted site for carcinogenic risk assessment.

\begin{tabular}{|c|c|c|c|c|c|c|c|c|c|c|c|}
\hline \multirow{2}{*}{\multicolumn{2}{|c|}{ Receptor pathway }} & \multicolumn{9}{|c|}{ Average Daily Intake (ADI) values for Heavy Metals in $\mathrm{mg} / \mathrm{kg} /$ day } & \multirow[b]{2}{*}{ Total } \\
\hline & & Cd & $\mathbf{P b}$ & $\mathrm{Cr}$ & $\mathrm{Cu}$ & $\mathrm{Fe}$ & Mn & $\mathrm{Zn}$ & As & $\mathrm{Hg}$ & \\
\hline \multirow{4}{*}{ Adults } & Ingestion & $1.88 \mathrm{E}-05$ & 6.13E-04 & $4.20 \mathrm{E}-04$ & $8.69 \mathrm{E}-06$ & $2.56 \mathrm{E}-03$ & $2.54 \mathrm{E}-04$ & $3.28 \mathrm{E}-04$ & 0.00 & 0.00 & $4.20 \mathrm{E}-03$ \\
\hline & Inhalation & $2.9 \mathrm{E}-10$ & $9.43 \mathrm{E}-09$ & $6.46 \mathrm{E}-09$ & $1.34 \mathrm{E}-10$ & $3.94 \mathrm{E}-08$ & $3.91 \mathrm{E}-09$ & $5.04 \mathrm{E}-09$ & 0.00 & 0.00 & 6.47E-08 \\
\hline & Dermal & 4.67E-07 & $1.52 \mathrm{E}-05$ & $1.04 \mathrm{E}-05$ & $2.15 \mathrm{E}-07$ & $6.34 \mathrm{E}-05$ & $6.3 \mathrm{E}-06$ & $8.12 \mathrm{E}-06$ & 0.00 & 0.00 & $1.04 \mathrm{E}-04$ \\
\hline & Total & $1.93 \mathrm{E}-05$ & $6.28 \mathrm{E}-04$ & 4.30E-04 & $8.91 \mathrm{E}-06$ & $2.62 \mathrm{E}-03$ & $2.60 \mathrm{E}-04$ & $3.36 \mathrm{E}-04$ & 0.00 & 0.00 & 4.31E-03 \\
\hline \multirow{4}{*}{ Children } & Ingestion & $3.52 \mathrm{E}-06$ & $1.14 \mathrm{E}-04$ & $7.84 \mathrm{E}-05$ & $1.62 \mathrm{E}-06$ & $4.78 \mathrm{E}-04$ & $4.75 E-05$ & $6.12 \mathrm{E}-05$ & 0.00 & 0.00 & $7.84 \mathrm{E}-04$ \\
\hline & Inhalation & $1.35 \mathrm{E}-10$ & $4.4 \mathrm{E}-09$ & $3.01 \mathrm{E}-09$ & $6.24 \mathrm{E}-11$ & $1.84 \mathrm{E}-08$ & $1.83 \mathrm{E}-09$ & 2.35E-09 & 0.00 & 0.00 & $3.02 \mathrm{E}-08$ \\
\hline & Dermal & $4.51 \mathrm{E}-07$ & $1.47 \mathrm{E}-05$ & $1.00 \mathrm{E}-05$ & $2.08 \mathrm{E}-07$ & $6.12 \mathrm{E}-05$ & $6.08 \mathrm{E}-06$ & 7.84E-06 & 0.00 & 0.00 & $1.00 \mathrm{E}-04$ \\
\hline & Total & $3.97 \mathrm{E}-06$ & $1.29 \mathrm{E}-04$ & $8.84 \mathrm{E}-05$ & $1.83 \mathrm{E}-06$ & $5.39 \mathrm{E}-04$ & $5.36 \mathrm{E}-05$ & $6.90 \mathrm{E}-05$ & 0.00 & 0.00 & 8.85E-04 \\
\hline
\end{tabular}


Table 11. Hazard quotients for the ingestion pathway of children and adults population in soil from the polluted and unpolluted site for non-carcinogenic risk assessment.

\begin{tabular}{lcccc}
\hline \multirow{2}{*}{ Metals/Groups } & \multicolumn{2}{c}{ Children } & \multicolumn{2}{c}{ Adults } \\
\cline { 2 - 5 } & Polluted & Unpolluted & Polluted & Unpolluted \\
\hline Cadmium & $1.60 \mathrm{E}-01$ & $8.21 \mathrm{E}-02$ & $1.17 \mathrm{E}-02$ & $8.80 \mathrm{E}-03$ \\
Lead & $1.39 \mathrm{E}+00$ & $3.71 \mathrm{E}-01$ & $1.49 \mathrm{E}-01$ & $3.97 \mathrm{E}-02$ \\
Chromium & $6.12 \mathrm{E}-01$ & $3.05 \mathrm{E}-01$ & $6.56 \mathrm{E}-02$ & $3.26 \mathrm{E}-02$ \\
Copper & $4.44 \mathrm{E}-03$ & $5.11 \mathrm{E}-04$ & $4.47 \mathrm{E}-04$ & $5.48 \mathrm{E}-05$ \\
Iron & n.a & n.a & n.a & n.a \\
Manganese & n.a & n.a & $7.26 \mathrm{E}-04$ & n.a \\
Zinc & $6.77 \mathrm{E}-03$ & $2.38 \mathrm{E}-03$ & $1.44 \mathrm{E}-02$ & $2.55 \mathrm{E}-04$ \\
Arsenic & $1.35 \mathrm{E}-01$ & 0.00 & 0.00 & 0.00 \\
Mercury & 0.00 & 0.00 & & 0.00 \\
\hline
\end{tabular}

n.a $=$ not available.

Table 12. Hazard quotients for the inhalation pathway of children and adults population in soil from the polluted and unpolluted site for non-carcinogenic risk assessment.

\begin{tabular}{lcccc}
\hline \multirow{2}{*}{ Metals/Groups } & \multicolumn{2}{c}{ Children } & \multicolumn{2}{c}{ Adults } \\
\cline { 2 - 5 } & Polluted & Unpolluted & Polluted & Unpolluted \\
\hline Cadmium & $5.41 \mathrm{E}-05$ & $2.77 \mathrm{E}-05$ & $2.32 \mathrm{E}-05$ & $1.19 \mathrm{E}-05$ \\
Lead & n.a & n.a & n.a & n.a \\
Chromium & $2.35 \mathrm{E}-03$ & $1.17 \mathrm{E}-03$ & $1.01 \mathrm{E}-03$ & $5.02 \mathrm{E}-04$ \\
Copper & n.a & n.a & n.a & n.a \\
Iron & n.a & n.a & n.a & n.a \\
Manganese & n.a & n.a & n.a & n.a \\
Zinc & n.a & n.a & n.a & n.a \\
Arsenic & $5.18 \mathrm{E}-06$ & 0.00 & $2.22 \mathrm{E}-06$ & 0.00 \\
Mercury & 0.00 & 0.00 & 0.00 & 0.00 \\
\hline
\end{tabular}

n.a $=$ not available.

Table 13. Hazard quotients for the dermal pathway of children and adults population in soil from the polluted and unpolluted site for non-carcinogenic risk assessment.

\begin{tabular}{lcccc}
\hline \multirow{2}{*}{ Metals/Groups } & \multicolumn{2}{c}{ Children } & \multicolumn{2}{c}{ Adults } \\
\cline { 2 - 5 } & Polluted & Unpolluted & Polluted & Unpolluted \\
\hline Cadmium & $2.05 \mathrm{E}-03$ & $1.05 \mathrm{E}-03$ & $4.25 \mathrm{E}-04$ & $2.18 \mathrm{E}-04$ \\
Lead & n.a & n.a & n.a & n.a \\
Chromium & n.a & n.a & n.a & n.a \\
Copper & $8.74 \mathrm{E}-04$ & $1.01 \mathrm{E}-04$ & $1.81 \mathrm{E}-04$ & $2.09 \mathrm{E}-05$ \\
Iron & n.a & n.a & n.a & n.a \\
Manganese & n.a & n.a & $7.19 \mathrm{E}-\mathrm{a}-04$ & n.a \\
Zinc & $3.47 \mathrm{E}-04$ & $1.22 \mathrm{E}-03$ & $3.57 \mathrm{E}-03$ & $2.53 \mathrm{E}-04$ \\
Arsenic & $3.45 \mathrm{E}-03$ & 0.00 & 0.00 & 0.00 \\
Mercury & 0.00 & 0.00 & & 0.00 \\
\hline
\end{tabular}

n.a $=$ not available. 
Table 14. Hazard Index for the Children and Adults Population in soil from the polluted and unpolluted site for non-carcinogenic risk assessment.

\begin{tabular}{lcccc}
\hline \multirow{2}{*}{ Metals/Groups } & \multicolumn{2}{c}{ Children } & \multicolumn{2}{c}{ Adults } \\
\cline { 2 - 5 } & Polluted & Unpolluted & $1.76 \mathrm{E}-02$ & Unpolluted \\
\hline Cadmium & $1.62 \mathrm{E}-01$ & $8.32 \mathrm{E}-02$ & $1.49 \mathrm{E}-01$ & $9.02 \mathrm{E}-03$ \\
Lead & $1.39 \mathrm{E}+00$ & $3.71 \mathrm{E}-01$ & $6.67 \mathrm{E}-02$ & $3.97 \mathrm{E}-02$ \\
Chromium & $6.15 \mathrm{E}-01$ & $3.06 \mathrm{E}-01$ & $6.58 \mathrm{E}-02$ & $3.32 \mathrm{E}-02$ \\
Copper & $6.13 \mathrm{E}-01$ & $3.05 \mathrm{E}-01$ & n.a & $3.27 \mathrm{E}-02$ \\
Iron & n.a & n.a & n.a & n.a \\
Manganese & n.a & n.a & $1.44 \mathrm{E}-03$ & n.a \\
Zinc & $1.02 \mathrm{E}-02$ & $3.60 \mathrm{E}-03$ & $1.800 \mathrm{E}-02$ & $5.08 \mathrm{E}-04$ \\
Arsenic & $1.52 \mathrm{E}-01$ & 0.00 & 0.00 & 0.00 \\
Mercury & 0.00 & 0.00 & & 0.00 \\
\hline
\end{tabular}

n.a $=$ not available .

When HQ and HI values are less than 1 , the population will not have any obvious risk, but if the values exceed one, this may lead to concern for potential non carcinogenic effects (USEPA, 1989; Kamunda et al., 2016; Šukalić et al., 2018). For both the children and adult population, calculated values of HQ were less than one in injection, inhalation and dermal pathways with the exception of lead which had HQ value of 1.39 for the ingestion pathway of children population exposed to the polluted soil site. The HI values for adults and children population exposed to the polluted and unpolluted sites were below one, indicating no risk to human health due to oral, Inhaled and dermal exposures investigated with heavy metals from the soil, except for $\mathrm{Pb}$ for children exposed to the polluted sites with $\mathrm{HI}$ value $>1$. This measured $\mathrm{HI}$ value $>1$ for $\mathrm{Pb}$ in children for oral intake shows a potential risk to human health. Luo et al. (2012) expressed concern for the non-cancerous risk of oral $\mathrm{Pb}$ for children; albeit the value of $\mathrm{HI}$ was lower than 1 . The potential noncancerous risk for adults' and children's health was explored by Oluseye et al. (2013) due to exposure to heavy metals in Nigeria in 2013. The risk assessment results indicated that the greatest risks to adults' and children's health is mainly related to $\mathrm{Pb}$. Likewise, for the children population, the total HI from the polluted site was 1.55 while for the unpolluted, the total HI was $6.97 \times 10^{-1}$. For the adult population, the total HI for the polluted site was $1.69 \times 10^{-1}$ while for the unpolluted site, the total HI was $7.54 \times 10^{-2}$. Overall, the total HI for both adults and children exposed to the polluted site was 1.72 while for the unpolluted, the total HI for both adult and children population exposed to the unpolluted site was $7.77 \times 10^{-1}$.

This high value expunged in the polluted soil site indicated heavy metal pollution that may pose a very high noncancer health risk to children living around the area. The results also indicated that, in both adults and children exposed to the polluted and unpolluted sites, the oral pathway contributes the greatest to noncarcinogenic risk followed by the inhalation pathway. Dermal is the least contributor to the risk.

\section{Carcinogenic risk assessment of heavy metals for adults and children}

The excess lifetime cancer risks for adults and children are calculated separately from the average contribution of the individual heavy metals in soil for all the pathways using Equations (6) and (7). Based on the carcinogenic risk values of the calculated $A D I$ values presented in Tables 9 and 10, the results of the excess lifetime cancer risks are presented in Tables 15 and 18. 
Table 15. Risk Pathway for the ingestion pathway of children and adults population in soil from the polluted and unpolluted site for carcinogenic risk assessment.

\begin{tabular}{lcccc}
\hline \multirow{2}{*}{ Metals/Groups } & \multicolumn{2}{c}{ Children } & \multicolumn{2}{c}{ Adults } \\
\cline { 2 - 5 } & Polluted & Unpolluted & Polluted & Unpolluted \\
\hline Cadmium & n.a & n.a & n.a & n.a \\
Lead & $3.64 \mathrm{E}-06$ & $9.73 \mathrm{E}-07$ & $1.95 \mathrm{E}-05$ & $5.21 \mathrm{E}-06$ \\
Chromium & $7.87 \mathrm{E}-05$ & $3.92 \mathrm{E}-05$ & $4.22 \mathrm{E}-04$ & $2.10 \mathrm{E}-04$ \\
Arsenic & $2.31 \mathrm{E}-06$ & 0.00 & $1.24 \mathrm{E}-05$ & 0.00 \\
\hline
\end{tabular}

n.a = not available.

Table 16. Risk pathway for the inhalation pathway of children and adults population in soil from the polluted and unpolluted site for carcinogenic risk assessment.

\begin{tabular}{lcccc}
\hline \multirow{2}{*}{ Metals/Groups } & \multicolumn{2}{c}{ Children } & \multicolumn{2}{c}{ Adults } \\
\cline { 2 - 5 } & Polluted & Unpolluted & Polluted & Unpolluted \\
\hline Cadmium & $1.66 \mathrm{E}-09$ & $8.52 \mathrm{E}-10$ & $3.57 \mathrm{E}-09$ & $1.83 \mathrm{E}-09$ \\
Lead & $6.91 \mathrm{E}-06$ & $1.85 \mathrm{E}-06$ & $1.48 \mathrm{E}-05$ & $3.96 \mathrm{E}-06$ \\
Chromium & $2.48 \mathrm{E}-07$ & $1.24 \mathrm{E}-07$ & $5.32 \mathrm{E}-07$ & $2.65 \mathrm{E}-07$ \\
Arsenic & $8.88 \mathrm{E}-11$ & 0.00 & $1.90 \mathrm{E}-10$ & 0.00 \\
\hline
\end{tabular}

n.a $=$ not available

Table 17. Risk pathway for the dermal pathway of children and adults population in soil from the polluted and unpolluted site for carcinogenic risk assessment.

\begin{tabular}{lcccc}
\hline \multirow{2}{*}{ Metals/Groups } & \multicolumn{2}{c}{ children } & \multicolumn{2}{c}{ adults } \\
\cline { 2 - 5 } & polluted & unpolluted & polluted & unpolluted \\
\hline Cadmium & n.a & n.a & n.a & n.a \\
Lead & n.a & n.a & n.a & n.a \\
Chromium & n.a & n.a & n.a & n.a \\
Arsenic & $2.96 \mathrm{E}-07$ & 0.00 & $3.06 \mathrm{E}-07$ & 0.00 \\
\hline
\end{tabular}

n.a = not available.

Table 18. Risk total for the children and adults population in soil from the polluted and unpolluted site for carcinogenic risk assessment.

\begin{tabular}{lllll}
\hline \multirow{2}{*}{ Metals/Groups } & \multicolumn{2}{c}{ Children } & \multicolumn{2}{c}{ Adults } \\
\cline { 2 - 5 } & \multicolumn{1}{c}{ Polluted } & Unpolluted & Polluted & Unpolluted \\
\hline Cadmium & $1.66 \mathrm{E}-09$ & $8.52 \mathrm{E}-10$ & $3.57 \mathrm{E}-09$ & $1.83 \mathrm{E}-09$ \\
Lead & $1.05 \mathrm{E}-05$ & $2.82 \mathrm{E}-06$ & $3.43 \mathrm{E}-05$ & $9.17 \mathrm{E}-06$ \\
Chromium & $7.90 \mathrm{E}-05$ & $3.93 \mathrm{E}-05$ & $4.22 \mathrm{E}-04$ & $2.10 \mathrm{E}-04$ \\
Arsenic & $2.60 \mathrm{E}-06$ & 0.00 & $1.27 \mathrm{E}-05$ & 0.00 \\
\hline
\end{tabular}

n.a $=$ not available.

The carcinogenic risk was calculated based on $\mathrm{Pb}, \mathrm{Cd} \mathrm{Cr}$ and As. The US Environmental Protection Agency considers acceptable for regulatory purposes a cancer risk in the range of $1 \times 10^{-6}$ to $1 \times 10^{-4}$ (USEPA, 2004). On the other hand, South Africa, considers the Individual cancer risk limit to be $5 \times 10^{-6}$ (GSA, 2006). The cancer risk for adults and children in the polluted area was found to be $4.69 \times 10^{-4}$ and $9.21 \times 10^{-5}$, respectively while the cancer risk for adults in the unpolluted area was found to be $2.19 \times 10^{-4}$ and $4.21 \times 10^{-5}$ for children. Overall, the total risk for both adults and children exposed 
to the polluted site was $5.61 \times 10^{-4}$ while for the unpolluted, the total risk for both adult and children population exposed to the unpolluted site was $2.61 \times 10^{-4}$. In the study area, adults are therefore more at risk than children. The ingestion route seems to be the major contributor to excess lifetime cancer risk followed by the dermal pathway.

\section{Conclusion}

Based on the results obtained in the soil from the crude oil polluted sites, the heavy metals varied significantly and decreased in the order of $\mathrm{Mn}>\mathrm{Fe}>\mathrm{Pb}>$ $\mathrm{Zn}>\mathrm{Cr}>\mathrm{Cu}>\mathrm{Cd}>\mathrm{As}>\mathrm{Hg}$. Compared with recommended maximum permissible limits from FAO/WHO, EU and South Africa (SA), concentration of $\mathrm{Pb}$ in the polluted site was found to be the higher while concentrations of $\mathrm{Cu}$ and $\mathrm{Zn}$ were found to be lower. $\mathrm{Cr}$ was found to be greater than the limit depicted by FAO/WHO and SA but lower than the EU limit. Likewise, Cd content was above FAO/WHO and EU limits but lower than SA limit As and $\mathrm{Hg}$ concentrations were lower compared with all the three recommended permissible limits. The results also indicated that, in both adults and children, the oral pathway was the greatest contributor to carcinogenic and non-carcinogenic risk followed by the inhalation pathway. The dermal pathway was the least contributor to cancer and non-cancer risk. Based on the results obtained in this study, it can be concluded that soils in the polluted site are seriously polluted by heavy metals. There is critical need to put in place regulations to protect residents from heavy metal pollution in the environment and subsequent remediation of the polluted soil.

\section{Conflict of interest}

The authors declare that they have no conflict of interest.

\section{References}

Ayangbenro, A. S.; Babalola, 0. 0. A new strategy for heavy metal polluted environments: A review of microbial biosorbents. International Journal of Environmental Research and Public Health, v. 14, no. 94, p. 1-6, 2017.

Chukwuma, C. C.; Onuah, C. L.; Nwauche, K. T.; Ohanador, R.; Chukwu, C. N; Enobong, E. Periodic effects of crude oil pollution on some nutrient elements of soils treated over a 90 day period using Schwenkia americana L. and Spermacoce ocymoides Burm. $\mathrm{f}$. International Journal of Advances in Scientific Research and Engineering, v. 4, no. 12, p. 7-15, 2018.

DPR - Department of Petroleum Resources. Environmental guidelines and standards for the petroleum industry in Nigeria (EGASPIN). Abuja, Nigeria: Ministry of Petroleum and Natural Resources, 2002.

IARC - International Agency for Research on Cancer. Cadmium. In: IARC. Monographs on the evaluation of carcinogenic risks to humans. Lyon, France: IARC Scientific Publications, 1993. p. 119-238.

Kamunda, C.; Mathuthu, M.; Madhuku, M. Health risk assessment of heavy metals in soils from Witwatersrand Gold Mining Basin, South Africa. International Journal of Environmental Research and Public Health, v. 13, p. 663-674, 2016.

Kamunda, C.; Mathuthu, M.; Madhuku, M. Assessment of radiological hazards from gold mine tailings in Gauteng Province, South Africa. International Journal of Environmental Research and Public Health, v. 13, p. 138, 2016b.

Luo, X. S.; Ding, J.; Xu, B. Incorporating bioaccessibility into human health risk assessments of heavy metals in urban park soils. Science Total of Environment, v. 424, p. 88-96, 2012. 
Mwegoha, W.; Kihampa, C. Heavy metal contamination in agricultural soils and water in Dares Salaam City, Tanzania. African Journal of Environmental Science and Technology, v. 4, no. 11, p. 763-769, 2010.

NJDEP - New Jersey Department of Environmental Protection. Soil cleanup criteria. New Jersey: NJDEP, 1996. (Proposed cleanup standards for contaminated sites, NJAC, 7:26D).

Oluseye, O. C.; Ojo, F. P.; Oyewumi, O. M.; Ayodele, 0.A. Potential health risk assessment for soil heavy metal contamination of Sagamu, South-West Nigeria due to cement production. International Journal of Applied Science and Technology, v. 3, no. 2, p. 89-96, 2013.

Rashid, M. H.; Fardous, Z.; Chowdhury, M. A. Z.; Alam, K.; Bari, L.; Moniruzzaman, M.; Gan, S. H. Determination of heavy metals in the soils of tea plantations and in fresh and processed tea leaves: An evaluation of six, digestion methods. Chemistry Central Journal, v. 10, no. 7, p. 2-20, 2016.

Riley, R. G.; Zachara, J. M.; Wobber, F. J. Chemical contaminants on DOE lands and selection of contaminated mixtures for subsurface science research, US-DOE. Washington, DC: Energy Resource Subsurface Science Program, 1992.

Su, C.; Jiang, L.; Zhang, W. A review on heavy metal contamination in the soil worldwide: Situation, impact and remediation techniques. Environmental Skeptics and Critics, v. 3, no. 2, p. 24-38, 2014.

Šukalić, A.; Ahmetović, N.; Mačkić, S.; Leto, A.; Džubur, A.; Antunović, B. Human health risk assessment of heavy metals from the agricultural soil in South Herzegovina. Agriculturae Conspectus Scientificus, v. 83, no. 1, p. 45-50, 2018.
Tchounwou, P. B.; Yedjou, C. G.; Patlolla, A. K.; Sutton, D. J. Heavy metals toxicity and the environment. NIH Public Access, v. 101, p. $131-164,2012$.

USEPA - United States Environmental Protection Agency. Risk assessment guidance for superfund. Volume 1: Human health evaluation manual (Part A). Washington, DC: Office of Emergency and Remedial Response, 1989.

USEPA - United States Environmental Protection Agency. Toxics release inventory: Public Data Release Report. 2001. Available from: <http://www.epa.gov/ tri/tridata/tri01>. Accessed on: Jan. 07, 2019.

USEPA - United States Environmental Protection Agency. Risk assessment guidance for superfund. Volume 1: Human health evaluation manual (Part E, Supplemental Guidance for Dermal Risk Assessment). Washington, DC: USEPA, 2004.

USEPA - United States Environmental Protection Agency. Cadmium compounds. Available from: <http://www.epa.gov/files/ documents/cadmium>. Accessed on: Oct. 06, 2018.

Wang, X.; Sato, T.; Xing, B. Health risks of heavy metals to the general public in Tianjin, China, via consumption of vegetables and fish. Science Total of Environment, v. 350, p. 28-37, 2005.

Wuana, R. A.; Okieimen, F. E. Heavy metals in contaminated soils: A review of sources, chemistry, risks and best available strategies for remediation. ISRN Ecology, v. 2011, p. 1-20, 2011.

License information: This is an open-access article distributed under the terms of the Creative Commons Attribution License, which permits unrestricted use, distribution, and reproduction in any medium, provided the original work is properly cited. 